\title{
Prediction of the arrival of peak nitrate concentrations at the water table at the regional scale in Great Britain
}

\author{
L Wang ${ }^{1}$, M E Stuart ${ }^{2}$, J P Bloomfield ${ }^{2}$, A S Butcher ${ }^{2}$, D C Gooddy ${ }^{2}$, A A McKenzie ${ }^{2}$, M A \\ Lewis $^{2}$, and A T Williams ${ }^{2}$ \\ ${ }^{1}$ British Geological Survey, Keyworth, Nottingham, NG12 5GG \\ ${ }^{2}$ British Geological Survey, Maclean Building, Wallingford, Oxfordshire, OX10 8BB
}

\begin{abstract}
:
A simple process-based approach to predict regional-scale loading of nitrate at the water table was implemented in a GIS for Great Britain. This links a nitrate input function, unsaturated zone thickness and lithologically-dependent rate of nitrate unsaturated zone travel to estimate arrival time of nitrate at the water table. The nitrate input function is the loading at the base of the soil and has been validated using unsaturated zone pore-water profiles. The unsaturated zone thickness uses groundwater levels based on regional-scale observations infilled by interpolated river base levels. Estimates of the rate of unsaturated zone travel are attributed from regional-scale hydrogeological mapping. The results indicate that peak nitrate loading may have already arrived at the water table for many aquifers, but that it has not where the unsaturated zone is relatively thick There are contrasting outcomes for the two main aquifers which have similar unsaturated zone velocities, the predominantly low relief Permo-Triassic sandstones and the Chalk, which forms significant topographic features. For about $60 \%$ of the Chalk, the peak input has not yet reached the water table and will continue to arrive over the next 60 years. The methodology is readily transferable and provides a robust method for estimating peak arrival time for any diffuse conservative pollutant where an input function can be defined at a regional scale and requires only depth to groundwater and a hydrogeological classification. The methodology is extendable in that if additional information is available this can easily be incorporated into the model scheme.
\end{abstract}




\section{INTRODUCTION}

This paper describes a first step in addressing the question of how the future long-term evolution of nitrate contamination in groundwater can be predicted at a regional or national scale. Within this overall aim, in order to estimate future temporal trends in nitrate concentration, there is a clear need to predict peak arrivals from the unsaturated zone at the water table.

Nitrate contamination of groundwater has long been recognised as an important public health issue (Comley, 1945). To protect drinking water resources and to avoid eutrophication of surface waters the European Union has set a limit of $11.3 \mathrm{mg} \mathrm{N} \mathrm{L}^{-1}$ for all groundwater (Nitrates Directive 91/676/EEC). In addition, the Water Framework Directive (EU Directive 2000/60/EC) requires that this level is to be achieved by 2015 if groundwater bodies are to achieve good status. Both regulatory imperatives and the necessity for long-term, capital investment planning by the water supply utilities require trends in concentration to be predicted.

Average concentrations have been rising in the United Kingdom and elsewhere since systematic measurements began in the middle of the last century. Recent estimates have shown the average trend in the UK to be an increase of between 0.34 and $0.51 \mathrm{mg} \mathrm{L}^{-1}$ year $^{-1}$ (European Environment Agency, 1999; Roy et al., 2007; Stuart et al., 2007). In England just over one third of the sites assessed by Stuart et al. (2007) exceeded the $50 \mathrm{mg} \mathrm{L}^{-1} \mathrm{EU}$ drinking water standard and it is estimated that $\sim 60 \%$ of all groundwater bodies will fail to achieve good status by 2015 (Defra, 2006; Gooddy and Besien, 2007; Rivett et al., 2007).

The majority of nitrate in groundwater is derived from diffuse pollution from agriculture (Foster, 2000; Defra, 2006) with the rest from sewage sludge disposal to land, atmospheric deposition and point sources. In the late 1970s the importance of storage of nitrate in unsaturated zone porewater was recognised (Foster and Crease, 1974; Young et al. 1976; Foster and Young, 1980; Oakes et al., 1981). Since then much effort has been focussed on understanding the processes associated with nitrate transport and degradation (Spears, 1979; Wellings and Bell, 1980; Lawrence and Foster, 1986; Geake and Foster, 1989; Mathias et al., 2007, Rivett et al., 2007), on mapping the spatial extent of nitrate contamination of groundwater (Hong et al. 2007; Rivett et al., 2007) and aquifer vulnerability to nitrate contamination (Palmer, 1987, Foster, 1993, Lake et al., 2003). More recently the impact on groundwater-supported ecosystems has also been considered (Hinsby et al., 2008; Smith et al., 2008). 
Pioneering work in understanding nitrate leaching beneath different land-use practices and subsequent movement to groundwater was carried out in the UK by Young et al. (1976) and Foster et al. (1982) who drilled cored boreholes through the Chalk unsaturated zone to obtain profiles of the porewater nitrate concentration as a function of depth. Unsaturated zone travel time was addressed using tritium as a tracer (Young et al., 1976; Geake and Foster, 1989). This body of work showed how the loading of nitrate in the unsaturated zone had significantly increased due to post-1945 agricultural intensification. Subsequently a large number of porewater profiles collected for the major aquifers of the United Kingdom have been collated by Stuart (2005). A study in Sweden by Hoffmann et al. (2000) shows a similar picture to that observed in the UK.

More recently some researchers have used a risk-based approach in the assessment of vulnerability to nitrate pollution using GIS methods at the national (Lake et al., 2003) or regional (Wang and Yang, 2008) scale. Lake et al. (2003) used four spatial data layers based on surface leaching (taken from the MAGPIE model of Lord and Anthony, 2000), aquifer type, superficial cover and soil type to provide the basis for a new set of groundwater Nitrate Vulnerable Zones. Wang and Yang (2008) used many more layers for their catchment scale model of nitrate vulnerability including nitrate loading, depth to water table, net recharge, soil type, aquifer type, impact of unsaturated zone media, and the hydraulic conductivity of the aquifer. Wang and Yang (2008) devised this scheme to guide the activities of groundwater pollution prevention at the catchment scale. To obtain such a level of detailed spatial layers at the national or regional scale would be extremely problematic with many of the required datasets either incomplete or non-existent.

Process-based models, typically at the source to catchment scale, have been used to provide estimates of future trends (Whitehead et al., 1998), but as a wide range of factors affect nitrate fate and transport these models tend to be source or catchment specific. Consequently, it is difficult to generalise observations from these process-based predictive models and they do not enable systematic assessments of future trends in average nitrate concentration. The application of complex GIS models is only currently practical at the catchment scale (Wang and Yang, 2008).

In order to predict changes in average behaviour over a regional area it is necessary to use a generic methodology with an appropriate level of conceptual complexity. This paper describes a simple accounting procedure implemented in a GIS using a single nitrate input function, newly-derived, regional-scale groundwater level mapping for Great Britain, and lithologically-dependent estimates of the rate of travel of nitrate through the unsaturated zone 
to map estimates of regional-scale loading of nitrate at the water table. This generic approach enables regional comparisons to be made between nitrate loading histories at the water table for different aquifers. The methodology is readily transferable to other areas and provides a robust method for estimating peak arrival time for any diffuse conservative pollutant where an input function can be defined at a regional scale and requires only depth to groundwater and a hydrogeological classification. It is amenable to further development to include additional factors, such as soil and unsaturated zone degradation or dispersion.

\section{METHODS}

\section{Simple conceptual model}

A simple conceptual model has been developed to predict nitrate arrival time at the water table and implemented in a GIS. The first order control on trends in nitrate concentration in groundwater is the loading of spatial nitrate at the water table. In this model the distribution of nitrate arriving at the water table depends on three functions: the nitrate input at the land surface (the temporally varying but spatially uniform leaching of nitrate from the base of the soil); the rate of travel of nitrate through the unsaturated zone (spatially dependent on variations in hydrolithological characteristics); and the thickness of the unsaturated zone (Figure 1). The unsaturated zone thickness and nitrate velocity are combined to estimate the spatial distribution of nitrate travel time in the unsaturated zone and from this the input year for nitrate reaching the water table at any defined time. The nitrate input function over time can then be used to estimate the concentration reaching the water table at any point and defined time.

Denitrification is considered to be the dominant nitrate attenuation process in the subsurface with other nitrate depletion mechanisms unlikely to be important (Rivett et al. 2007: 2008). Kinniburgh et al. (1994) concluded that denitrification beneath the soil zone in the unsaturated zone of UK aquifers was probably insignificant relative to the flux passing through and the assumption made here is that there is no attenuation due to denitrification.

The presence of thick low-permeability superficial deposits will limit the amount of nitrate which is able to enter the aquifer and this was accounted for by switching off the input function where such deposits are present. Spatio-temporal variations in recharge rate, nitrate degradation, and diffusive and dispersive processes in the soil and unsaturated zones will all influence the loading of nitrate at the water table, but here these factors are considered to be secondary and were not considered. Factors such as average saturated groundwater flow and 
groundwater discharge rates which will affect trends in nitrate concentration in the aquifer as a whole were also excluded.

The model maintains sufficient flexibility so that greater sophistication (either with refinement of local parameters or to the model structure) can be subsequently introduced, if needed. It is based on the following assumptions:

- nitrate input/loading is from the base of the soil,

- movement is through the matrix only in dual-porosity strata,

- the mass of nitrate in the unsaturated zone is preserved except where the bedrock is overlain by low-permeability superficial deposits,

- nitrate moves vertically from the land surface to the water table,

- nitrate moves at a constant velocity through the unsaturated zone, and

- there is no hydrodynamic dispersion of nitrate in the unsaturated zone.

Movement of water, and hence nitrate, through the unsaturated zone is predominantly vertical. Even if at the local-scale there is some lateral movement, because the GIS model is based on a grid with a resolution of $1 \mathrm{~km} \times 1 \mathrm{~km}$, the assumption of vertical movement is also reasonable. The assumption of a constant velocity implicitly requires an assumption that for each unit $\left(1 \mathrm{~km}^{2}\right)$ cell in the GIS the unsaturated zone has homogeneous hydrodynamic characteristics, i.e. the velocities used in the model are effective velocities at the resolution of the model associated with a given hydrolithological unit. Hydrodynamic dispersion of nitrate in the unsaturated zone, due to both mechanical dispersion and diffusion, will occur, but was not accounted for. Both these processes will act to attenuate the peak concentration and lead to a spread in arrival time at the water table. The leading edge of the peak will therefore arrive earlier than predicted and there will also be a tail leading to some longer arrival times.

Of these model functions, the unsaturated zone velocity and the depth to water are assumed to be constant over the modelled period and can be relatively well characterised from current hydrogeological data, whereas nitrate leaching will have changed over time and is based on a series of assumptions. Each of the three functions is described below, including notes on the data sources used in this study (Figure 1). This is then followed by a description of how the model has been implemented in the GIS.

\section{Unsaturated zone velocities}

The model requires an effective vertical velocity of nitrate in the unsaturated zone for each 1 km by 1 km cell. The new digital 1:625,000 hydrogeological mapping of Great Britain (BGS, 
2010) has been used as the basis for assigning the spatially dependent nitrate velocities. The bedrock geological map that this is based on can be viewed at http://www.bgs.ac.uk/products/digitalmaps/digmapgb_625.html. This was divided into three main classes of aquifer units: aquifers with significant intergranular flow, aquifers in which flow is virtually all through fractures and other discontinuities and rocks with essentially no groundwater (Figure 2). Within the first two classes aquifers were assessed as high, moderate or low productivity. Using a combination of these classes and other factors such as grain-size and age (as a surrogate for induration) each of the bedrock formations was attributed with a water movement rate.

For some of the major aquifers, particularly on the Chalk, there has been a large body of work looking at rates of water movement through the unsaturated zone (e.g. Foster and Smith-Carington, 1980; Geake and Foster 1989; Barraclough et al., 1994) summarised by Chilton and Foster (1991). Table 1 shows the range of velocities obtained for the Cretaceous age Chalk, Triassic Sherwood Sandstone and Jurassic Lincolnshire Limestone from Chilton and Foster (1991). These authors also showed that rates obtained from tritium porewater profiles agree with values simply calculated by dividing the effective rainfall (net value after losses by evaporation) by the total matrix porosity. Table 1 also shows mean velocities calculated in this way using the mean values of effective rainfall figures taken from Chilton and Foster (1991). A similar value for the Chalk in Belgium (about $1 \mathrm{~m} \mathrm{year}^{-1}$ ) was obtained by Brouyère et al. (2004). The rate for the Lincolnshire Limestone is based on relatively few profiles compared to the Chalk and Sherwood Sandstone.

It can be seen that the values for unsaturated zone flow rates are several orders of magnitude (three to five) lower than flow velocities in the saturated zone. The model does not account for any bypass flow so it is likely that in reality these values represent the lower end of the actual velocity range and will therefore lead to projected unsaturated travel times at the upper end of the range. These measured rates were also used for similar rocks, so the Sherwood Sandstone value was used for all the Permo-Triassic sandstones and conglomerates in Great Britain and the Lincolnshire Limestone value was used for all the other Jurassic oolitic limestone formations, although the mapped units include other lithologies.

Smith et al. (1970) used tritium profiles to measure rates of water movement through low permeability strata and obtained a value of $0.09 \mathrm{~m} \mathrm{year}^{-1}$ for the Oxford Clay Formation. The latter value relates to autumn recharge through cracks (fractures) produced by a summer soil moisture deficit. A value of $0.1 \mathrm{~m}$ year $^{-1}$ was therefore used for this and similar clay strata. For all other formations, the values were attributed heuristically using the criteria in Table 2. 
Where formations formed multi-layered aquifers and intergranular flow was significant in the permeable horizons, the prevalence of clay layers, as well as the predominant grain-size of the permeable horizons, was taken into account, to obtain the value.

The model also does not take account of the wide variation in precipitation across Great Britain with over $2000 \mathrm{~mm} /$ year in upland areas of the north and west and less than $600 \mathrm{~mm}$ in parts of East Anglia (Met Office, 2010). However, most of the important aquifers are located away from the north and west and it has been assumed that unsaturated zone annual travel time within aquifers is uniform at the national scale.

\section{Superficial deposits}

The 1:625 000 hydrogeological map for the UK currently only shows the bedrock. So areas where the bedrock is overlain by low permeability superficial deposits (such as the Chalk of parts of Yorkshire, Lincolnshire and East Anglia and the Sherwood Sandstone of Cheshire) are portrayed incorrectly as having a highly productive aquifer at outcrop. In reality, these areas have a low recharge potential and there will not be significant amounts of recharge reaching the bedrock aquifer. Additionally, denitrification is likely to occur within such superficial deposits and hence potential nitrate inputs to the underlying aquifer will be low (Jørgensen et al, 2004; Fragalà and Parkin, 2010). These areas have been masked out of the GIS analysis in this study using data from a national map of the recharge potential of the superficial deposits (SNIFFER, 2006: Griffiths, 2011) that has been produced based on the characteristics of the uppermost (mapped) deposits. The recharge potential mapping uses a domain (genesis) approach and incorporates both primary and secondary lithologies for mapped units. Areas where both the primary and secondary recharge potentials are low for everywhere north of the limit of glaciation (i.e. excluding periglaciated domains plus areas of fluvial and coastal and estuarine deposits south of this limit) were used to delineate areas where no nitrate is assumed to reach the underlying aquifers.

\section{Depth to groundwater at the national scale}

A representative depth to groundwater has been estimated for each $1 \mathrm{~km} \times 1 \mathrm{~km}$ cell across Great Britain based on:

1. groundwater levels inferred from river base levels (RBL),

2. groundwater levels taken from contours on published hydrogeological maps (generally at 1:100,000 scale) and from other digitised contours 
3. point measurements from national networks of observation wells and from well inventories.

Areas of low permeability rocks are difficult to deal with by this approach so to avoid unrealistic estimations of groundwater levels in low permeability areas with pronounced topography the dataset was filtered so that the maximum thickness of the unsaturated zone was constrained to no more than 10 metres in areas underlain by low permeability rocks.

Measurements that characterise confined aquifers are of no value in calculating the thickness of the unsaturated zone and were excluded from the mapping process. The only dataset with national coverage is that inferred from river base levels, and this was used as the primary dataset in this study, validated by contoured data over major aquifers and by point measurements.

The RBL surface is an interpolated surface that assumes that rivers are hydraulically connected to aquifers, and approximate to the water table in the aquifer (Figure 3). The river network used is derived from a gridded Digital Surface Model (NextMap DSM), with drainage densities appropriate to different hydrolithological units. The depth to groundwater was obtained by subtracting the mean groundwater levels from the NextMap DSM mean topographic elevations for each $1 \mathrm{~km}$ by $1 \mathrm{~km}$ grid square (Figure 4). The resulting dataset was compared to field measurements from 30 index boreholes in the National Ground Water Level network. The modelled water levels are within the observed ranges, where observation boreholes were unconfined. Where discrepancies were noted these were generally a result of observations being made close to valley floors, and hence where water tables are shallower than the average over a one kilometre square, which is the value used in the model. The model gives a realistic water table in permeable unconfined aquifers, and close to surface drainage.

\section{Nitrate input function}

The nitrate input function used in this study, shown as a red line in Figure 5, is based on estimates of the time-varying nitrate content found in the unsaturated zone immediately beneath the soil layer. The curve is divided into six time slices or spans. A continuous input function could have been used; however six time slices were chosen to make the GIS modelling tractable. The time slices were defined with reference to previous studies of nitrate loading as follows:

Span 1, from 1925 to 1940, is a constant input of $25 \mathrm{~kg} \mathrm{~N} \mathrm{ha}^{-1}$ year $^{-1}$ (Foster et al., 1982). This reflects the pre-war level of nitrate input to groundwater and is based on a low level of 
industrialisation and very limited use of non-manure based fertilisers (Addiscott, 2005). Span 2, from 1940 to 1955 , consists of a $1 \mathrm{~kg} \mathrm{~N} \mathrm{ha}^{-1}$ year $^{-1}$ rise in input from $25 \mathrm{~kg} \mathrm{~N} \mathrm{ha}^{-1}$ in 1940 to $40 \mathrm{~kg} \mathrm{~N} \mathrm{ha}^{-1}$ in 1955 . This rise is the result of the gradual intensification of agriculture during and just after WWII and based on data included in Foster et al. (1982). Span 3, from 1955 to 1975, shows a more rapid rise of $1.5 \mathrm{~kg} \mathrm{~N} \mathrm{ha}^{-1}$ year ${ }^{-1}$ from $40 \mathrm{~kg} \mathrm{~N}^{-1}$ in 1955 to $70 \mathrm{~kg} \mathrm{~N} \mathrm{ha}{ }^{-1}$ in 1975. This steeper rise is due to increases in the use of chemical based fertilisers to meet the food needs of an expanding population (Addiscott et al., 1991). A similar rate of rise is identified by Foster et al. (1982) who use the tritium peak of 1963 as a marker in their profiles taken from agricultural and non-agricultural land. Span 4, from 1975 to 1990 , is a constant peak nitrate input value based on the average value obtained by Lord et al. (1999) beneath a range of land-uses and remains constant over this time frame. The $70 \mathrm{~kg} \mathrm{~N} \mathrm{ha}^{-1}$ value is similar, although slightly lower, than that obtained by Foster et al. (1982) for arable land in the Chalk of East Yorkshire. There will of course be some areas which have been subject to very intensive cultivation and where values will have been much higher, but these will be offset by other less-intensively fertilised areas. For span 5, from 1991 to 2020, there is a gradual decline of $1 \mathrm{~kg} \mathrm{~N} \mathrm{ha}^{-1}$ year $^{-1}$ from $70 \mathrm{~kg} \mathrm{~N} \mathrm{ha}^{-1}$ in 1991 to 40 $\mathrm{kg} \mathrm{N} \mathrm{ha}^{-1}$ in 2020 due to restrictions on fertiliser application as a result of the implementation of nitrate sensitive areas (Lord et al., 1999) and nitrate vulnerable zones, and also due to a general reduction in nitrate application. This is evidenced by a reduction of about $30 \%$ in fertiliser use between 1990 and 2000 (ADAS, 2003). Finally, span 6, from 2020 to 2050 (the end of the modelled input), is a constant $40 \mathrm{~kg} \mathrm{~N} \mathrm{ha}^{-1}$ assuming a return to nitrate input levels similar to those associated with early intensified farming in the mid-1950s.

The nitrate input function was compared with nitrate concentration data from the porewaters of almost 300 cored boreholes from major aquifers (Stuart, 2005). The function was converted from $\mathrm{kg} \mathrm{N} \mathrm{ha}^{-1}$ to $\mathrm{mg} \mathrm{N}^{-1}$ by assuming a constant effective rainfall of $250 \mathrm{~mm}_{\text {year }}{ }^{-1}$. The porewater data were used to back estimate the nitrate in infiltration entering the unsaturated zone during the past 100 years, using the date at which the samples were taken, their depth below ground surface and an estimate of velocity in the unsaturated zone derived from tritium profiles (Table 1). These are shown on Figure 5 as black dots with annual averages as blue crosses. These averages show an excellent agreement with the overall modelled input function. The apparent large applications between 1995 and 2000 may be an artefact of both the relatively small number of recent data points and the focus of recent studies on areas with a nitrate problem. 


\section{The GIS model}

A raster data based spatial-temporal GIS model was developed to implement the conceptual model described above (Figure 1). The resolution of the raster data used was $1 \mathrm{~km} \times 1 \mathrm{~km}$. Nitrate travel time in the unsaturated zone was calculated by overlaying different aquifer transport velocities and the depth to groundwater datasets. Spatial distribution maps of nitrate input (from the ground surface) year in each year between 1925 and 2209 (284 years) were derived using the equation:

$$
V N I_{x, y}^{n}=\left\{\begin{array}{cc}
n-\text { Integer }\left(T T_{x, y}+0.5\right) & {[1925,2050]} \\
0 & \text { else }
\end{array}\right.
$$

where, $V N I_{x y}^{\mathrm{n}}$ is the grid value of the nitrate input year at the location of $(\mathrm{x}, \mathrm{y})$ for the year $\mathrm{n}$ when the nitrate reaches the water table; $T T_{x, y}$ is the nitrate travel time at the location $(\mathrm{x}, \mathrm{y})$; 1925 is the first year of the nitrate input function and 2050 the last year.

Based on the nitrate input function, the nitrate input before 1940 was constant, and 1925, which is the earliest year for nitrate input mentioned by Foster et al. (1982), was selected as the start year for modelling in this study.

Maps of nitrate input years were reclassified using the GIS based on the data from the nitrate input function, to generate yearly nitrate concentration maps at the water table, starting in 1925. Then, mean nitrate concentrations at the water table of each aquifer in different years were calculated. Finally, the time series of mean concentration arriving at the water table for each aquifer were calculated.

\section{RESULTS}

The distribution of travel times for the unsaturated zone from the surface to the water table for nitrate, and indeed for any conservative tracer, is presented in Figure 6. The calculated nitrate travel time ranges between 1 and over 400 years. On the basis of the model, nitrate is projected to reach the water table of $88.1 \%$ of the areas of Great Britain within 20 years of input. It is predicted to take 1 year for nitrate to reach the water table in roughly $27 \%$ of areas.

The areas of selected hydrogeological units which have not yet been affected by predicted peak nitrate concentrations are shown in Table 3. This includes significant areas of both major and locally important aquifers. The White and Grey Chalk, parts of the Carboniferous (Fell Sandstone, Yoredales, Millstone Grit and Coal Measures), and the Devonian sandstones of Scotland (Middle Old Red Sandstone, Stratheden, Strathmore and Arbuthnott-Garvock 
Groups) are all strata which have pronounced relief and the model predicts a thick unsaturated zone.

Other units, such as the Palaeogene Lambeth Group have significant unaffected areas predicted because they have a slow rate of unsaturated zone travel and have a relatively limited outcrop which abuts units with pronounced relief. The process of averaging to $1 \mathrm{~km}$ squares gives an apparently thick unsaturated zone. The peak nitrate concentration in other aquifers with significant intergranular flow, such as the Cretaceous Greensands, and karstic aquifers, such as the Zechstein Group dolomites and the Dinantian limestones, are predicted to have predominantly arrived and these aquifers are therefore not shown in Table 3 . The remaining aquifers in Table 3 include the important Permo-Triassic sandstones and conglomerates and the Jurassic oolites where the predicted nitrate peak has arrived over the majority of the aquifer but the large outcrop area means that over $200 \mathrm{~km}^{2}$ are projected to be still unaffected. Table 3 also gives the estimated mean arrival time for nitrate to the remaining unaffected areas and Figure 7 is a map showing estimates of how long after 2009 the peak nitrate input could reach the water table. The average arrival time is predicted to be about 36 years, but more than 50 years over some areas, most notably parts of the Chalk aquifer (Figure 7).

Although the major aim of the paper is to predict the peak nitrate arrival time at the water table, nitrate concentrations at the water table in different aquifers were also calculated merely for demonstrating the trends of nitrate entering the aquifers. Calculated concentrations of nitrate at the water table vary spatially even in the same aquifer unit due to the spatial variation of the thickness of the unsaturated zone. In order to simplify the concentration results for data analysis, the average nitrate concentrations at the water table for each hydrogeological unit in different years were also calculated using the GIS model. This shows that using a uniform input function for water arriving at the water table of poor aquifers (aquitards) could have a higher nitrate concentration than that arriving in major aquifers in 2009, mostly because of the short travel time for nitrate in the unsaturated zones of these poor aquifers.

The predicted concentrations are likely to be pessimistically high since the model does not account for attenuation by dispersion and because the nitrate concentration calculation at the water table in this study was based on the assumption that nitrate stays at the water table and does not transport or dilute in groundwater. The calculated nitrate concentrations at the water table are much higher than the actual nitrate concentration in groundwater, for 
example, the concentrations of nitrate arriving at the water table for the major aquifers measured in abstracted water (Rivett et al., 2007).

On the basis of the input function, and unsaturated zone thickness and water velocity, a time series for nitrate concentration arriving at the water table of each aquifer in 1925-2070 was created. Figure 8 shows the modelled time series of the average nitrate concentration at the water table of the White Chalk and of the Permo-Triassic sandstones and conglomerates up to 2050. It is predicted from the model that peak nitrate has not yet reached the water table in about $60 \%$ of the Chalk due to the deep water table in many areas, and the average nitrate concentrations reaching the Chalk water table will peak about 2020.

\section{DISCUSSION}

The model predicts that rapid transit times result from either a thin unsaturated zone or a high unsaturated zone velocity, and that for areas of aquifers where the unsaturated zone is thick, peak concentrations may not yet have arrived. The main factor highlighted to be causing the difference between the major aquifers of the Chalk and the Permo-Triassic sandstones, which have similar unsaturated zone velocities, is unsaturated zone thickness. In other countries, significant unsaturated zone travel times are also predicted for the Chalk: in the Hesbaye and Noor catchments in Belgium (van Lanen and Dijksma, 1999; Brouyère et al., 2004) and the Seine catchment in France (Ledoux et al. 2007).

Many studies of thick unsaturated zones are for arid settings, for example for the Negev chalk of Israel (Nativ et al, 1995), the High Plains aquifer of the USA (Gurduk et al., 2006; McMahon et al., 2006), and residence times can be extremely long (Bromley et al. 1997). However, where land is irrigated, similar issues to those described for humid regions, such as the UK, are observed. Spalding and Kitchen (1988) describe nitrate holdup beneath fertilised and irrigated cropland in the thick vadose zone of a loess aquifer in the USA. Johnston et al. (1998) dated groundwater and estimated future nitrate concentrations in a glacial aquifer beneath a thick unsaturated zone in Ontario. In parts of Malta beneath irrigated agriculture, a thick limestone unsaturated zone may lead to long-term problems with nitrate (Stuart et al. 2010).

For the major aquifers unsaturated zone travel time was based on measured values and estimated travel times are considered to have relatively low uncertainty as measured values are broadly within a factor of 2 of the mean value used here. Low productivity aquifers and aquitards were effectively excluded by constraining the water level to preclude long 
unsaturated zone storage. There is greater uncertainty for other strata where values were estimated. Unsaturated zone thickness for the major aquifers is also based primarily on measured water levels and is well-characterised. The modelled surface used to infill water level values is effective at characterising areas of shallow groundwater as these are constrained by rivers and these areas also therefore have low uncertainty. It may underestimate the depth to water in highly abstracted aquifers and overestimate the depth to water in areas of low permeability and high relief; hence it was constrained to $10 \mathrm{~m}$. In our GIS model, the nitrate travel time is calculated by dividing the depth of water table (D) by the velocity (V) for each cell. So the relationship between nitrate travel time, and $\mathrm{D}$ and $\mathrm{V}$ can be treated as linear. The model should be similarly sensitive to D and V and should represent the major aquifers well. The greatest uncertainty will be for moderate productivity aquifers with high relief (for example the Coal Measures) as these have the most poorly constrained V and D. These are commonly cyclical strata, forming layered aquifers, and will have very variable V.

The nitrate input function is the most uncertain in magnitude and since it depends on a number of assumptions and poorly-characterised parameters. This function is generalised for the whole of Great Britain and as such does not take into account large differences in land use and agricultural practices, as well as climatic variation across Great Britain, all of which affect soil nitrogen leaching rates. An estimate of the present distribution of nitrate leaching from agriculture is shown in Johnson et al (2007). In addition it is largely based on data from Foster et al. (1982) which is taken from rural and often arable settings and so is not necessarily representative of inputs from urban or non-agricultural areas, such as moorland. As such, and when compared with the porewater profile measurements shown in Figure 5, the curve is very much an upper boundary to input concentrations. However this controls the projected concentration at the water table. Indeed, it is the shape and the temporal position of these time spans which gives the characteristic series of breakthroughs as the 'peak nitrate' moves through the unsaturated zone. The overall shape and timing of the inflections used here are in very good agreement with those found by Hoffmann et al. (2000) for nitrate inputs from Swedish agriculture and some confidence can be placed on these.

The model is constructed to allow further development to incorporate additional factors, such as regional variations in historical nitrate applications. Using a series of input functions for different parts of the country is likely to generate a slightly different pattern of breakthrough on an aquifer by aquifer basis - especially in areas where there is little or no agriculture. However, these input functions would still be subject to error, for instance, the 
problem of accounting for variable urban inputs and the general paucity of data that exists for minor aquifer systems as well as the significant changes in land-use that have and still can occur. Another approach might be to use an N-leaching model such as IMPACT (Andrews et al., 1997) or MAGPIE (Lord and Anthony, 2000), as used by Johnson et al. (2007), but such models can only generate historic datasets if sufficient application data is available. At the scale that this GIS model works, it is considered that the single input function provides a parsimonious and fit for purpose solution to predicting future groundwater nitrate trends.

Additional factors that would need to be incorporated to allow the prediction of future nitrate concentrations in groundwater could include soil and unsaturated zone degradation, regional estimates of unsaturated zone velocity taking account of variations in recharge, unsaturated zone dispersion, and most importantly, saturated zone thickness. Although the nitrate concentrations calculated in this study do not represent nitrate concentrations in groundwater, they can be treated as indicators of the rate and amount of nitrate leached into aquifers. Attenuation factors in the saturated zone including denitrification, aquifer permeability and groundwater abstraction rate (controls borehole catchment area) would also be factors that would need to be incorporated into the model in order to simulate nitrate fate and transport processes in aquifers and hence the trend of nitrate concentrations at boreholes and groundwater sources. Burow et al. (2010) showed that redox status was more important than nitrate input for understanding saturated zone nitrate concentrations in the USA.

A more sophisticated methodology for relating water levels and aquifer units for $1 \mathrm{~km}$ squares where there are two or more aquifer units mapped could be applied. Currently the geology is attributed to each $1 \mathrm{~km}$ square using the unit with the greatest area. Water levels are attributed to $50 \mathrm{~m}$ squares and these are averaged to $1 \mathrm{~km}^{2}$. A method where the water level is estimated using the properties of the major unit only could be used. This would deal more effectively with units, such as the Thanet Sand Formation, which have narrow outcrops adjacent to units with greater relief (in this example, the Chalk).

It is important to note that there are two main aquifer types where the assumptions made in the model are not valid. Firstly there are areas of poorly permeable rocks which appear as grey areas in Figure 7. These do not provide significant groundwater resources and particularly in the north and western parts of Great Britain are not cultivated. For these areas the manual limiting of depth to groundwater ensures that such areas appear in the 'already reached' class in Figure 7. If calculation of concentrations were to be attempted a different approach for these areas would be required. Secondly confined aquifers are not properly represented. For these aquifers nitrate arrival times calculated by this method are related to 
outcrop areas. In reality, for relatively thin aquifers, such as the Lincolnshire Limestone, these areas tend to be unsaturated and abstraction takes place from the confined aquifer where the nitrate movement may be different.

The finding here that peak nitrate inputs are projected to have not yet affected about $60 \%$ of the Chalk aquifer is in good agreement with Stuart and Kinniburgh (2005) who estimated $51 \%$ of the Chalk sites for which trends were calculated would not be anticipated to exceed the EU standard by 2015. This present study not only suggests that the standard will be exceeded but that concentrations will remain high for the next 2-3 decades as the entire nitrate peak reaches the water-table. This is consistent with a detailed study in the Chalk at the catchment scale in central southern England by Jackson et al. (2007) that suggested peak concentrations would be reached in 2025 and with Roy et al. (2007) who predicted that Chalk groundwater bodies in SW England would exceed the standard between 2015 and 2062. The implications for the regulatory bodies and for UK water utilities, especially in the hard pressed water resource areas that the Chalk serves, are severe and require serious long-term planning.

In contrast peak nitrate inputs are projected to have already affected all of the PermoTriassic sandstones and conglomerates. Stuart and Kinniburgh (2005) found that for the Permo-Trias $46 \%$ of sites already exceeded the EU standard by 2000 and predicted that by 2015 this would have risen to 59\%; similarly 54\% of Lincolnshire Limestone sites were affected in 2000, but predicted this to fall to $45 \%$ by 2015 . These predictions are statistical and based solely on previous trends and do not take account of changes to nitrate input. They also relate to the whole aquifer rather than to concentrations at the water table. However peak nitrate predictions from this work are consistent with the Permo-Triassic sandstones and the Lincolnshire Limestone both being more heavily and/or more quickly affected than the Chalk.

\section{CONCLUSIONS}

A simple, process-based model, comprising a single historical nitrate input function, a newlyderived estimate of depth to groundwater and lithologically-dependent unsaturated zone velocity, has been successfully incorporated into a national-scale GIS and used to predict the arrival times of nitrate at the water table for the whole of Great Britain. This generic approach has enabled comparisons to be made between nitrate loading histories at the water table for different aquifers. 
The model results indicate that peak nitrate loadings may have already arrived at the water table for many aquifers, including the Cretaceous Greensands, the Zechstein Group dolomites and the Dinantian limestones. For these aquifers, nitrate reaches the water table within 30 years of application and these rapid transit times result from a combination of thin unsaturated zones and/or high unsaturated zone velocities. Nitrate has also arrived in most of the Permo-Triassic sandstones and the Jurassic oolites.

For areas of aquifers where the unsaturated zone is thick, peak concentrations are yet to arrive, and these include parts of the Cretaceous Chalk, the Carboniferous Coal Measures, Yoredales and Millstone Grit of northern England and the Scottish Devonian sandstones. For about $60 \%$ of the Chalk aquifer, the peak nitrate input is projected not to have yet reached the water table and it may take decades for the full impact of nitrate to be seen in some areas.

The approach is readily applicable to a range of hydrogeological settings at a regional or national scale where the following critical factors can be derived: a nitrate input function, unsaturated zone travel times and depths to groundwater.

The model is constructed to allow further development to incorporate additional factors, such as regional variations in nitrate application and recharge, soil and unsaturated zone degradation or dispersion, and saturated zone thickness to allow the prediction of future nitrate concentrations in groundwater.

\section{ACKNOWLEDGEMENTS}

This paper is published with the permission of the Executive Director, British Geological Survey (NERC). The authors are grateful to Rose Hargreaves for assistance with GIS work related to the new BGS 1:625,000 hydrogeological mapping and to John Chilton for his review of this paper and some helpful suggestions.

\section{REFERENCES}

ADAS. 2003, Production and use of nitrogen fertilisers. Report for Defra Project NT2601. ADAS UK Ltd. http://randd.defra.gov.uk/Default.aspx?Menu=Menu\&Module=More\& Location=None\&Completed $=0 \&$ ProjectID=11771\#RelatedDocuments

Addiscott, TM 2005. Nitrate, Agriculture and the Environment. CAB International: Wallingford; 279.

Addiscott, TM, Whitmore, AP, Powlson, DS 1991. Farming, Fertilizers and the Nitrate Problem. CAB International: Wallingford; 170. 
Allen, DJ, Brewerton, LJ, Coleby, LM, Gibbs, BR, Lewis, MA, MacDonald, AM, Wagstaff, SJ, Williams. AT 1997. The physical properties of major aquifers in England and Wales, British Geological Survey Technical Report WD/97/34, Environment Agency R\&D Publication 8.

Andrews, RJ, Lloyd, JW, Lerner, DN 1997. Modelling of nitrate leaching from arable land into unsaturated soil and chalk -1 . Development of a management model for applications of sewage sludge and fertilizer. Journal of Hydrology 200: 179-197.

Barraclough, D. Gardner, CMK, Wellings, SR, Cooper, JD 1994. A tracer investigation into the importance of fissure flow in the unsaturated zone of the British Upper Chalk. Journal of Hydrology 156: 459-469

Bloomfield, JP, Brewerton, LJ, Allen, DJ 1995. Regional trends in matrix porosity and dry density of the Chalk of England, Quarterly Journal of Engineering Geology 28: S131-S142

British Geological Survey. 2010. Hydrogeological map of Great Britain, 1:625,000 scale. British Geological Survey: Keyworth, Nottingham.

Bromley, J, Edmunds, WM, Fellman, E, Brouwer, J, Gaze, SR, Sudlow, J, Taupin, J-D. 1997. Estimation of rainfall inputs and direct recharge to the deep unsaturated zone of southern Niger using the chloride profile method. Hydrogeology Journal 188-189: 139-154

Brouyère, SB, Dassargues, A, Hallet, V. 2004. Migration of contaminants through the unsaturated zone overlying the Hesbaye chalky aquifer in Belgium: a field investigation. Journal of Contaminant Hydrology 72: 135-164

Burow, KR, Nolan, BT, Rupert, MG, Dubrovsky, NM, in press, Nitrate in Groundwater of the United States, 1991-2003. Environmental Science and Technology.

Comley HH, 1945. Cyanosis in infants caused by nitrates in well water. Journal of the American Medical Association 129: 112-116

Council of European Communities. December 1991. Concerning the protection of waters against pollution caused by nitrates from agricultural sources (91/676/EEC).

Council of European Communities. 2001. Establishing the list of priority substances in the field of water policy and amending Directive 2000/60/EC (2455/2001/EC). Official journal of EC L331/1 
Defra. 2006. Nitrates in water - the current status in England (2006). ADAS report to Defra supporting paper D1 for the consultation on implementation of the Nitrates Directive in England.

European Environment Agency. 1999. Groundwater quality and quantity in Europe. Environmental Assessment Report 3.

Foster, SSD. 1993. The Chalk aquifer- its vulnerability to pollution. In The Hydrogeology of the Chalk of North-West Europe, Downing RA, Price M, Jones GP (eds). Clarendon Press: Oxford: $1-13$.

Foster, SSD. 2000. Assessing and controlling the impacts of agriculture on groundwater from barley barons to beef bans. Quarterly Journal of Engineering Geology and Hydrogeology 33: 263-280.

Foster, SSD, Crease, RI. 1974. Nitrate pollution of Chalk groundwater in East Yorkshire - a hydrogeological appraisal. Journal of the Institute of Water Engineer 28: 178-194.

Foster, SSD, Young, CP. 1980. Groundwater contamination due to agricultural land-use practices in the United Kingdom. In Aquifer Contamination \& Protection, UNESCO-IHP Studies and Reports in Hydrogeology Series, 30; 262-282.

Foster, SSD, Smith-Carington, AK 1980, The interpretation of tritium in the Chalk unsaturated zone, Journal of Hydrology 46: 343-364.

Foster SSD, Cripps, AC, Smith-Carington, AK 1982. Nitrate leaching to groundwater. Philosophical Transactions of the Royal Society of London B 296: 477-489.

Fragalà, AF, Parkin,G, 2010. Local recharge processes in glacial and alluvial deposits of a temperate catchment. Journal of Hydrology 389: 90-100

Geake, AK, Foster, SSD. 1989. Sequential isotope and solute profiling in the unsaturated zone of British Chalk. Hydrological Sciences Journal 34: 79-95.

Gooddy, DC, Besien, T. 2007. Introduction to the nitrate in groundwater papers. Quarterly Journal of Engineering Geology and Hydrogeology 40: 333.

Griffiths KJ, MacDonald AM, Robins NS, Merritt J, Booth SJ, Johnson D and McConvey PJ, 2011. Improving the characterisation of Quaternary deposits for groundwater vulnerability assessments using maps of recharge and attenuation potential. Quarterly Journal of Engineering Geology and Hydrogeology, 44: 49-61 
Gurduk, JJ, Hanson, RT, McMahon, PB, Bruce, BW, McCray, JE, Thyne, GD, Reedy, RC. 2006. Climatic variability in controls on unsaturated water and chemical movement, High Plains Aquifer, USA. Vadose Zone Journal 6: 533-547

Hinsby, K, Condesso de Melo, MT, Dahl, M 2008. European case studies supporting the derivation of natural background levels and groundwater threshold values for the protection of dependent ecosystems and human health. Science of the Total Environment 401: $1-20$.

Hoffmann, M, Johnsson, H, Gustafson, A, Grimvall, A. 2000. Leaching of nitrogen in Swedish agriculture - a historical perspective. Agriculture, Ecosystems and Environment 80: $277-290$.

Hong, N, White, JG, Weisz, R, Gumpertz, ML, Duffera, MG, Cassel DK. 2007. Groundwater nitrate spatial and temporal patterns and correlations: Influence of natural controls and nitrogen management. Vadose Zone Journal 6: 53-66.

Jackson, BM, Wheater, HS, Wade, AJ, Butterfield, D, Mathias, SA, Ireson, AM, Butler, AP, McIntyre, NR, Whitehead, PG. 2007. Catchment-scale modelling of flow and nutrient transport in the Chalk unsaturated zone. Ecological Modelling 209: 41-52.

Johnson, D, Fletcher, SW, Bray, K. 2007. Integrated assessment of nitrate concentrations for the designation of groundwater Nitrate Vulnerable Zones in England and Wales. Quarterly Journal of Engineering Geology \& Hydrogeology 40:407-415

Johnston, CT, Cook, PG, Frape, SK, Plummer, LN, Busenburg, E, Blackport, RJ. 1998. Groundwater age and nitrate distribution within a glacial aquifer beneath a thick unsaturated zone. Ground Water 36: 171-180

Jones, HK, Morris, BL, Cheney, CS, Brewerton, LJ, Merrin, PD, Lewis, MA, MacDonald, AM, Coleby, LM, Talbot, JC, McKenzie, AA, Bird, MJ, Cunningham, J, Robinson, VK. 2000. The physical properties of minor aquifers in England and Wales. British Geological Survey Technical Report WD/00/4, Environment Agency R\&D Publication 68.

Jørgensen, PR, Urup, J, Helstrup, T, Jensen, MB, Eiland, F, Vinther, FP. 2004. Transport and reduction of nitrate in clayey till underneath forest and arable land. Journal of Contaminant Hydrology 73: 207-226 
Kinniburgh, DG, Gale, IN, Gooddy, DC, Darling, WG, Marks, RJ, Gibbs, BR, Coleby, LM, Bird, MJ, West, JM. 1994. Denitrification in the unsaturated zones of the British Chalk and Sherwood Sandstone aquifers. British Geological Survey Technical Report WD/99/2

Lake, IR, Lovett, AA, Hiscock, KM, Betson, M, Foley, A, Sünnenberg, G, Evers, S. Fletcher, S. 2003. Evaluating factors influencing groundwater vulnerability to nitrate pollution: developing the potential of GIS. Journal of Environmental Management 68: 315-328.

Lawrence, AR, Foster, SSD. 1986. Denitrification in a limestone aquifer in relation to the security of low-nitrate groundwater supplies. Journal of the Institute of Water Engineering Sciences 40: 159-172.

Ledoux, E, Gomez, E, Monget, JM, Viavattene, C, Viennot, P., Ducharne A, Benoit, M, Mignolet, C, Schott, C, Mary, B. 2007. Agriculture and groundwater nitrate contamination in the Seine basin. The STICS-MODCOU modelling chain. Science of the Total Environment 375: 33-47

Lord, EI, Anthony, SG 2000. MAGPIE: A modelling framework for evaluating nitrate losses at national and catchment scales. Soil Use and Management. 16: 167-174.

Lord, EI, Johnson, PA, Archer, JR. 1999. Nitrate Sensitive Areas: a study of large scale control of nitrate loss in England. Soil Use and Management 15: 201-207.

Mathias, SA, Butler, AP, Ireson AM. Jackson, BM, McIntyre, N, Wheater, HS. 2007 Recent advances in modelling nitrate transport in the Chalk unsaturated zone, Quarterly Journal of Engineering Geology and Hydrogeology 40; 353-359

McMahon, PB, Dennehy, KF, Bruce, BW, Böhlke, JK, Michel, RL, Gurdak, JJ, Hurlbut, DB. 2006. Storage time and transit time of chemicals in thick unsaturated zones under rangeland and irrigated cropland, High Plains, United States. Water Resources Research 42: W03413

Met Office. 2010. Rainfall amount, annual average 1971-2000. http://www.metoffice.gov.uk/climate/uk/averages/ukmapavge.html

Nativ, R, Adar, E, Dahan, O, Geyh, M. 1995. Water recharge and solute transport through the vadose zone of fractured chalk under desert conditions. Water Resources Research 31: 253-261 
Oakes, DB, Young, CP, Foster, SSD. 1981. The effects of farming practices on groundwater quality in the United Kingdom. Science of the Total Environment 21: 17-30.

Palmer RC, 1987. Groundwater Vulnerability (7 maps and booklets covering Severn-Trent Water Authority area), Soil Survey and Land Research Centre: Cranfield

Rivett, MO, Smith, JNW, Buss, SR, Morgan, P. 2007. Nitrate occurrence and attenuation in the major aquifers of England and Wales. Quarterly Journal of Engineering Geology and Hydrogeology 40: 335-352.

Rivett, MO, Buss, SR, Morgan, P, Smith, JWN, Bemment, CD. 2008. Nitrate attenuation in groundwater: A review of biogeochemical controlling processes. Water Research 42: $4215-4232$.

Roy,S., Speed, C, Bennie, J, Swift, R, Wallace, P. 2007. Identifying the significant factors that influence temporal and spatial trends in nitrate concentrations in the Dorset and Hampshire Basin Chalk aquifer of Southern England. Quarterly Journal of Engineering Geology and Hydrogeoloy, 40: 377-392.

Smith, DB, Wearn, PL, Hichards, HJ, Rowe PC, 1970. Water movement in the unsaturated zone of high and low permeability strata by measuring natural tritium, Proceedings. IAEA Symposium on Isotope Hydrology, IAEA, Vienna, 73-87

Smith, JWN, Bonell, M, Gibert, J, McDowell, WH, Sudicky, EA, Turner, JV, Harris, RC. 2008. Groundwater-surface water interactions, nutrient fluxes and ecological response in river corridors: Translating science into effective environmental management. Hydrological Processes 22: 151-157.

SNIFFER. 2006. An approach to hydrogeological assessment of Quaternary deposits in the UK. Project WFD34, Scotland and Northern Ireland Forum for Environmental Research: Edinburgh.

Spalding, RF, Kitchen, LA. 1988. Nitrate in the intermediate unsaturated zone beneath irrigated cropland. Groundwater Monitoring \& Remediation 8: 89-95

Spears, DA. 1979. Porewater composition in the unsaturated zone of the Chalk, with particular reference to nitrates. Quarterly Journal of Engineering Geology and Hydrogeology 12: 97-105.

Stuart, ME. 2005. Development of nitrate profiles database. British Geological Survey Internal Report IR/05/058. 
Stuart, ME, Kinniburgh, DG. 2005. Nitrate trends in groundwater. British Geological Survey Internal Report IR/05/137R.

Stuart, ME, Chilton, PJ, Kinniburgh, DG, Cooper, DM. 2007. Screening for long-term trends in groundwater nitrate monitoring data. Quarterly Journal of Engineering Geology and Hydrogeology 40: 361-376.

Stuart ME, Maurice, L, Heaton, THE, Sapiano, M. Micallef Sultana, M, Gooddy, DC, Chilton, PJ. 2010. Groundwater residence time and movement in the Maltese Islands - a geochemical approach. Applied Geochemistry 25: 609-620

van Lanen, HAJ, Dijksma, R. 1999. Water flow and nitrate transport to a groundwater-fed stream in the Belgian-Dutch chalk region. Hydrological Processes 13: 295-307

Wang, JL, Yang, Y.S. 2008. An approach to catchment-scale groundwater nitrate risk assessment from diffuse agricultural sources: a case study in Upper Bann, Northern Ireland. Hydrological Processes 22: 4274-4286.

Wellings, SR, Bell, JP. 1980. Movement of water and nitrate in the unsaturated zone of Upper Chalk near Winchester, Hants, England. Journal of Hydrology 48: 119-136.

Whitehead, PG, Wilson, EJ, Butterfield, D. 1998. A semi-distributed Integrated Nitrogen model for multiple source assessment in Catchments (INCA): Part I - model structure and process equations. Science of the Total Environment 210: 547-558.

Young, CP, Oakes, DB, Wilkinson, WB. 1976. Prediction of future nitrate concentrations in groundwater. Ground Water 14: 426-438. 
Table 1 Rates of unsaturated water movement for selected major aquifers (measured ranges from Chilton and Foster (1991), mean porosity values from Bloomfield et al., (1995) and Allen et al (1991), mean velocity values calculated)

\begin{tabular}{|l|c|c|c|c|c|c|}
\hline \multirow{2}{*}{} & \multicolumn{2}{|c|}{$\begin{array}{c}\text { Porosity } \\
(\%)\end{array}$} & \multicolumn{2}{c|}{$\begin{array}{c}\text { Effective rainfall } \\
\text { (mm year }\end{array}$} & \multicolumn{2}{c|}{$\begin{array}{c}\text { Unsaturated zone velocity } \\
\text { (m year }\end{array}$} \\
\cline { 2 - 7 } & Range & Mean & Range & Mean & Range & Mean \\
\hline White Chalk Subgroup & $25-45$ & 33.1 & $150-350$ & 250 & $0.3-1.4$ & 0.76 \\
\hline Grey Chalk Subgroup & & 27.9 & & 250 & & 0.90 \\
\hline Lincolnshire Limestone Formation & $10-25$ & 18 & $150-250$ & 200 & $0.6-2.5$ & 1.11 \\
\hline Sherwood Sandstone Group & $15-35$ & 26 & $200-350$ & 275 & $0.6-2.3$ & 1.06 \\
\hline
\end{tabular}


Table 2 Attributed rates of unsaturated movement for rocks not included in Table 1

\begin{tabular}{|c|c|c|c|}
\hline Class & Type & Examples & $\begin{array}{c}\text { Unsaturated } \\
\text { zone flow rate } \\
\left(\mathbf{m ~ y e a r}^{-1}\right)\end{array}$ \\
\hline \multirow[t]{2}{*}{$\begin{array}{l}\text { Aquifers with } \\
\text { significant } \\
\text { intergranular flow }\end{array}$} & Predominantly sands & $\begin{array}{l}\text { Crag Group, Bracklesham and Barton Groups, Upper } \\
\text { Greensand Formation, Lower Greensand Group, Bridport } \\
\text { Sand Formation }\end{array}$ & 3 \\
\hline & Predominantly silts & Solent Group, Lambeth Group, Thanet Sand Formation & 0.3 \\
\hline \multirow[t]{3}{*}{ Fractured aquifers } & Karstic & $\begin{array}{l}\text { Zechstein Group dolomite, Dinantian limestone, Durness } \\
\text { Group }\end{array}$ & 10 \\
\hline & $\begin{array}{l}\text { Multi-layered Mesozoic } \\
\text { aquifers }\end{array}$ & Corallian Group, Mercia Mudstone Group & 1 \\
\hline & $\begin{array}{l}\text { All Palaeozoic (except } \\
\text { Zechstein Group dolomites and } \\
\text { Permian mudstones), igneous } \\
\text { and metamorphic rocks }\end{array}$ & $\begin{array}{l}\text { Old Red Sandstone Supergroup, Coal Measures Group, } \\
\text { Millstone Grit Group, granite, Lewisian complex }\end{array}$ & 1 \\
\hline \multirow[t]{2}{*}{ Aquitards } & Clays (Jurassic and younger) & $\begin{array}{l}\text { Thames Group, Kimmeridge Clay Formation, Oxford } \\
\text { Clay Formation, Lias Group }\end{array}$ & 0.1 \\
\hline & Permian mudstones & & 0.1 \\
\hline
\end{tabular}


Table 3. Areas predicted to be unaffected by peak nitrate input in 2009 in geological units with unaffected outcrop area of $200 \mathrm{~km}^{2}$ or more in Great Britain and future arrival time for the remaining $\mathbf{N}$ peak

\begin{tabular}{|c|c|c|c|c|c|}
\hline Unit (with lithology) & Age & $\begin{array}{l}\text { Unaffected area } \\
\left(\mathbf{k m}^{2}\right)\end{array}$ & $\begin{array}{l}\text { Total area } \\
\left(\mathbf{k m}^{2}\right)\end{array}$ & $\begin{array}{l}\text { Unaffected } \\
(\%)\end{array}$ & $\begin{array}{c}\text { Mean arrival } \\
\text { time (years) }\end{array}$ \\
\hline White Chalk Subgroup & Cretaceous & 9695 & 15817 & 61.3 & 42.2 \\
\hline Yoredale Group (limestone, sandstone, siltstone and mudstone) & Carboniferous & 2053 & 5813 & 35.3 & 36.3 \\
\hline Millstone Grit Group (mudstone, siltstone and sandstone) & Carboniferous & 1664 & 4793 & 34.7 & 34.7 \\
\hline $\begin{array}{l}\text { Pennine and South Wales Lower Coal Measures Formations (mudstone, siltstone, sandstone, } \\
\text { coal and ironstone) }\end{array}$ & Carboniferous & 1267 & 3690 & 34.3 & 25.8 \\
\hline $\begin{array}{l}\text { South Wales Upper Coal Measures Formation (mudstone, siltstone, sandstone, coal and } \\
\text { ironstone) }\end{array}$ & Carboniferous & 836 & 1537 & 54.4 & 57.7 \\
\hline Permo-Triassic sandstone and conglomerate & Permo-Triassic & 708 & 8956 & 7.9 & 16.2 \\
\hline Middle Old Red Sandstone (Scotland) (conglomerate, sandstone, siltstone and mudstone) & Devonian & 683 & 3263 & 20.9 & 26.7 \\
\hline Grey Chalk Subgroup & Cretaceous & 517 & 1661 & 31.1 & 23.8 \\
\hline Ravenscar Group (sandstone, siltstone and mudstone) & Jurassic & 490 & 833 & 58.8 & 30.1 \\
\hline Lambeth Group (clay, silt, sand and gravel) & Palaeogene & 419 & 1083 & 38.7 & 57.9 \\
\hline Arbuthnott-Garvock Group (sandstone with subordinate conglomerate, siltstone and mudstone) & Devonian & 394 & 2116 & 18.6 & 24.2 \\
\hline Inverclyde Group (sandstone, siltstone and mudstone) & Carboniferous & 369 & 1816 & 20.3 & 23.7 \\
\hline $\begin{array}{l}\text { Pennine and South Wales Middle Coal Measures Formations (mudstone, siltstone, sandstone, } \\
\text { coal and ironstone) }\end{array}$ & Carboniferous & 367 & 3051 & 12.0 & 18.9 \\
\hline Corallian Group (limestone, sandstone, siltstone and mudstone) & Jurassic & 280 & 830 & 33.7 & 29.4 \\
\hline Stratheden Group (sandstone and conglomerate) & Devonian & 268 & 1329 & 20.2 & 23.3 \\
\hline Clackmannan Group (cycles of limestone, mudstone, sandstone and siltstone) & Carboniferous & 231 & 1941 & 11.9 & 14.6 \\
\hline Great Oolite Group (sandstone, limestone and argillaceous rocks) & Jurassic & 223 & 3546 & 6.3 & 16.5 \\
\hline Inferior Oolite Group (limestone, sandstone, siltstone and mudstone) & Jurassic & 214 & 1803 & 11.9 & 23.8 \\
\hline Fell Sandstone Group (sandstone) & Carboniferous & 201 & 330 & 60.9 & 45.7 \\
\hline Strathmore Group (sandstone with subordinate conglomerate, siltstone and mudstone) & Devonian & 200 & 1190 & 16.8 & 28.7 \\
\hline
\end{tabular}


- Topography (BGS NextMap DTM)

- Water level contours (BGS 1:100,000 hydrogeological maps)

- $\quad$ Point water level data (BGS WellMaster database)

\section{GIS}

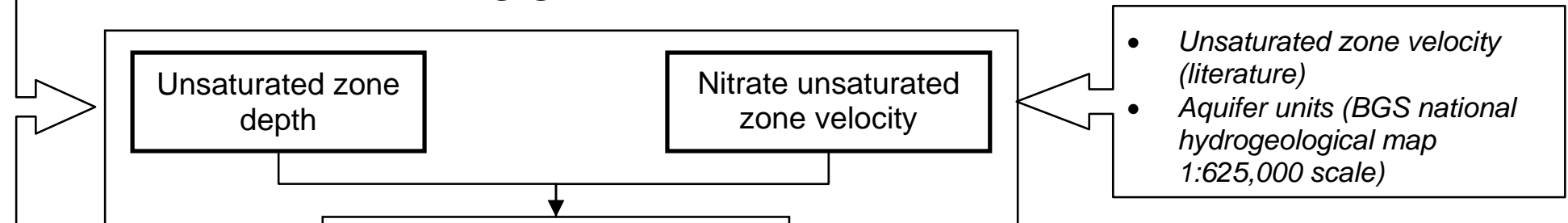

Spatial distribution of nitrate travel time in unsaturated zone

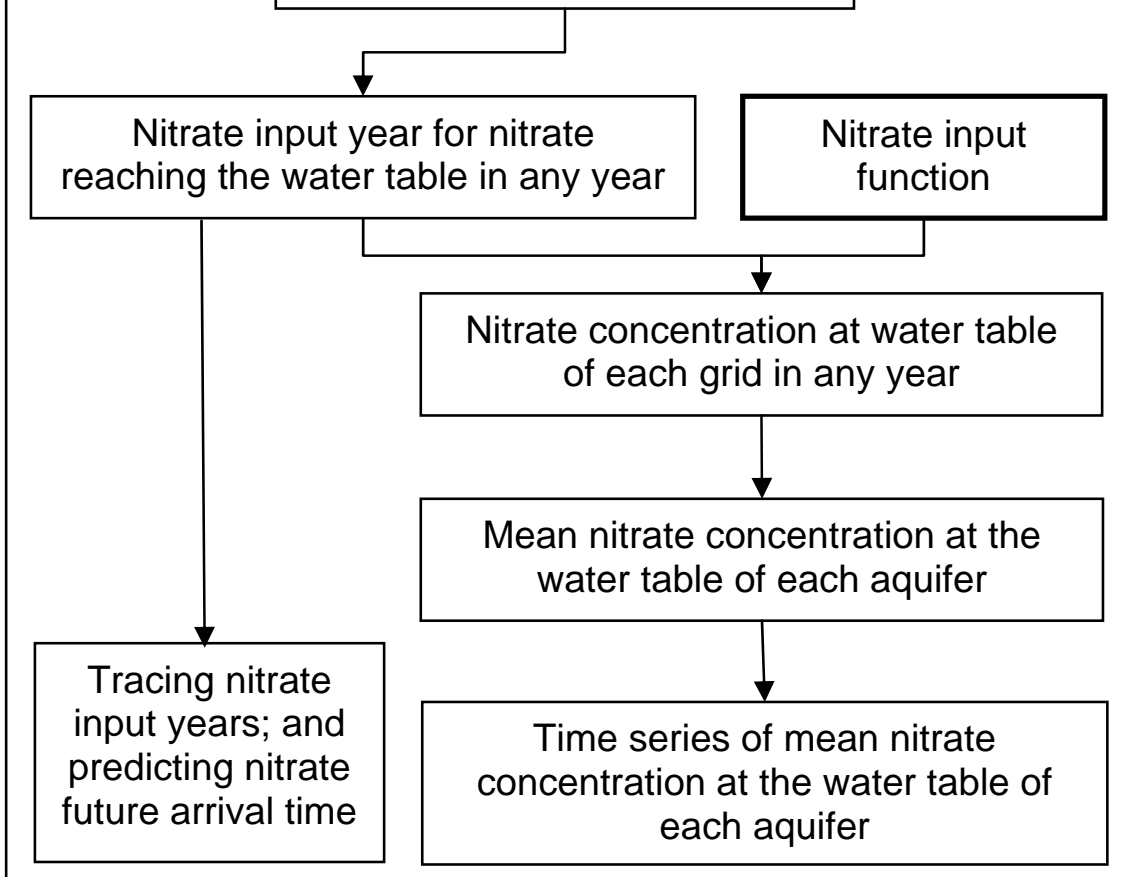

- Historical nitrate applications (literature)

- Nitrate porewater profiles (BGS database)

Figure 1. Flow chart of the spatial-temporal GIS model used in this study and main data sources 


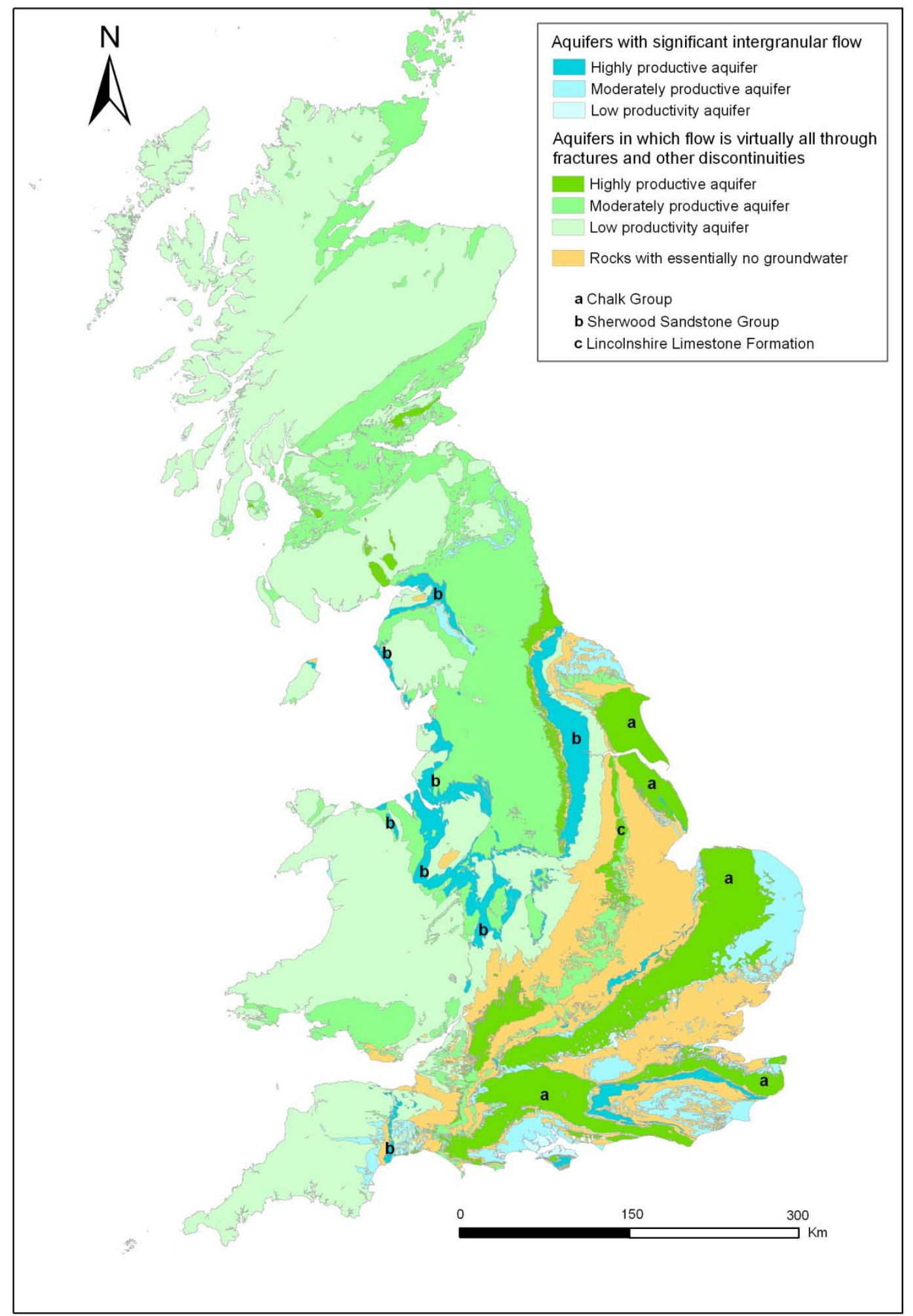

Figure 2. Simplified 1:625,000 scale hydrogeological map showing locations of major aquifers with unsaturated zone travel times attributed from measured values in Table 1 


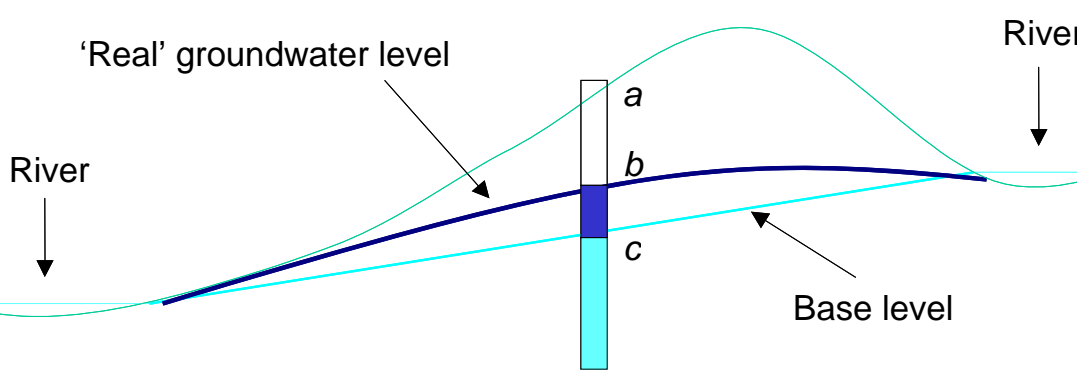

Figure 3. Interpolation of groundwater levels from topography and surface water information. In this cross section the base level has been interpolated between two rivers. A borehole has terrain surface $a$, a 'real' groundwater level at $b$ and a calculated base level at $c$. 


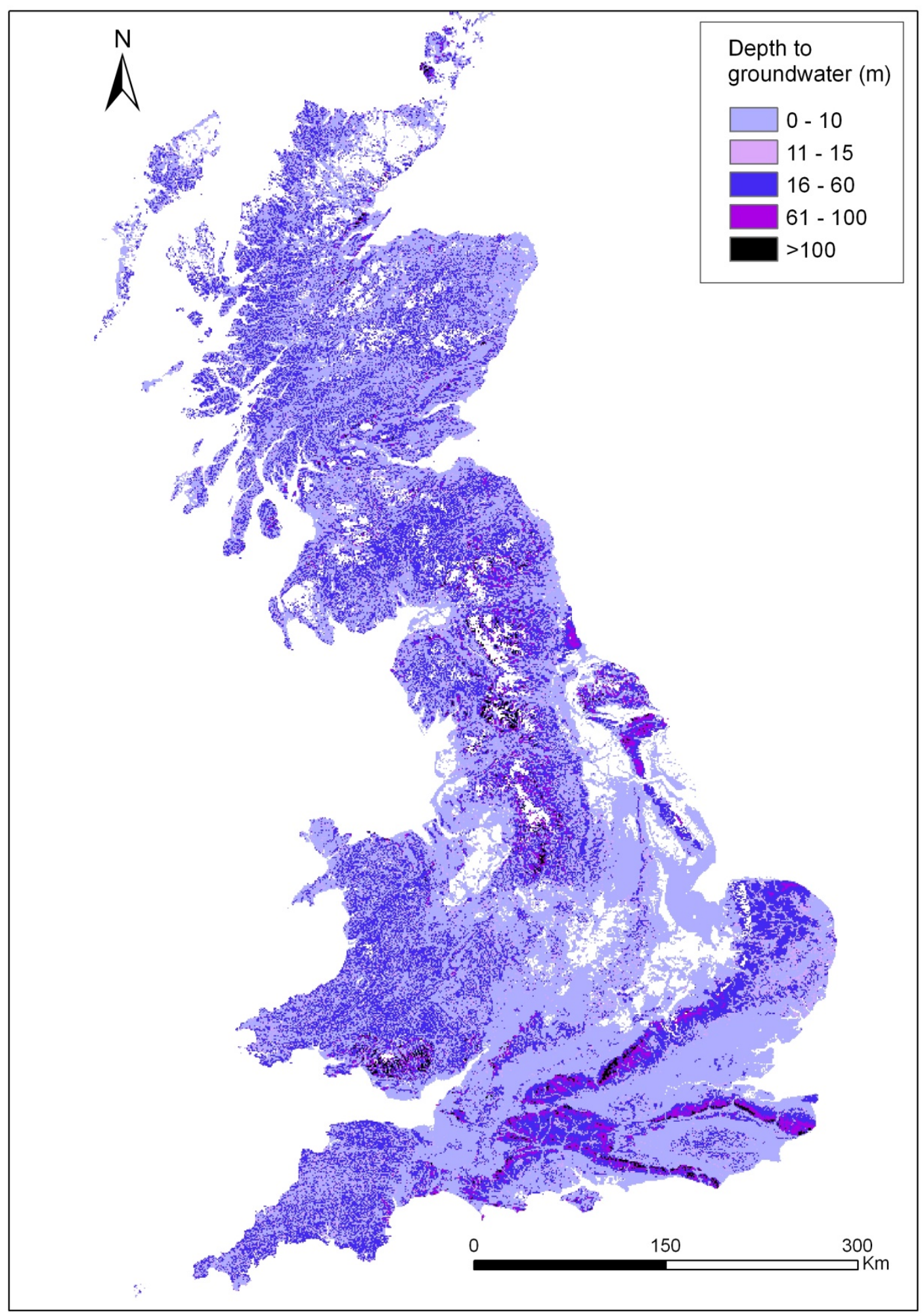

Figure 4. Depth to groundwater (unsaturated zone thickness) 


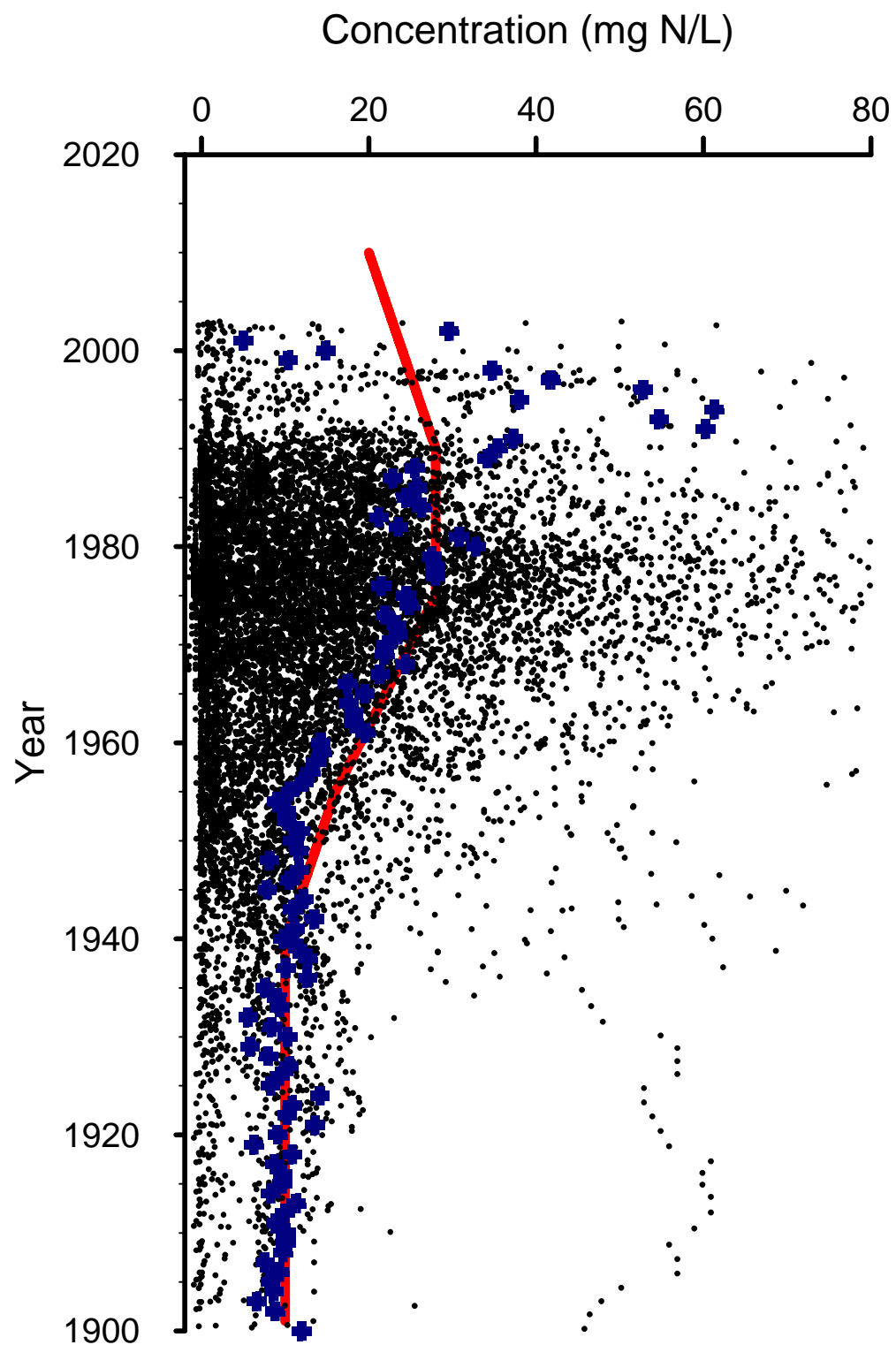

Figure 5. Nitrate input function. Solid line shows spans derived from literature data. Black dots show individual porewater nitrate concentrations from $\sim 300$ cored boreholes in the BGS database which have been back plotted to give base of the soil zone concentrations at their year of recharge calculated using depth in the profile and estimated unsaturated zone travel time. Blue crosses show mean nitrate concentration for a given year calculated from the porewater data. 


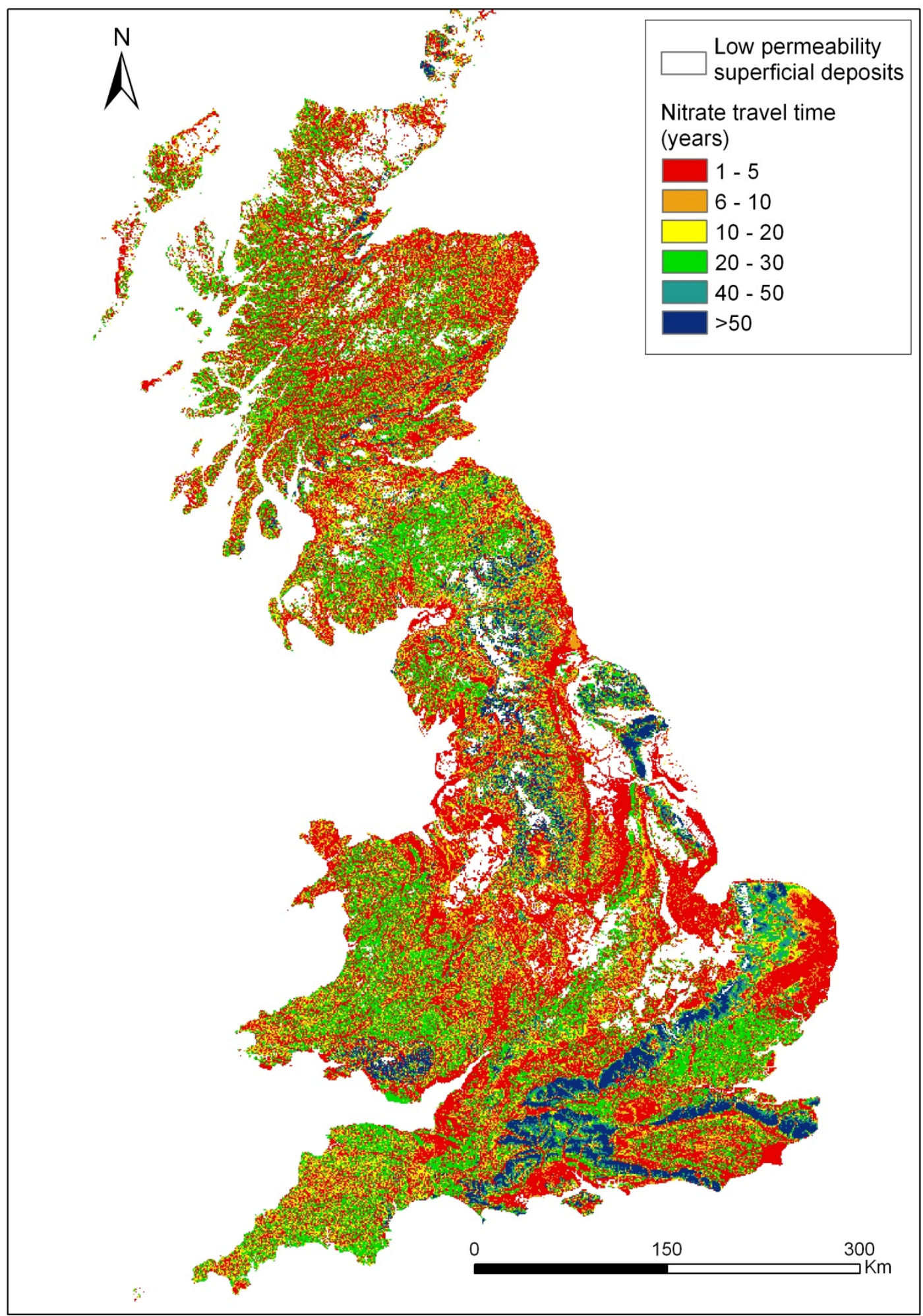

Figure 6. The distribution of predicted nitrate travel time in the bedrock unsaturated zone of Great Britain. Low permeability superficial deposits not coloured. 


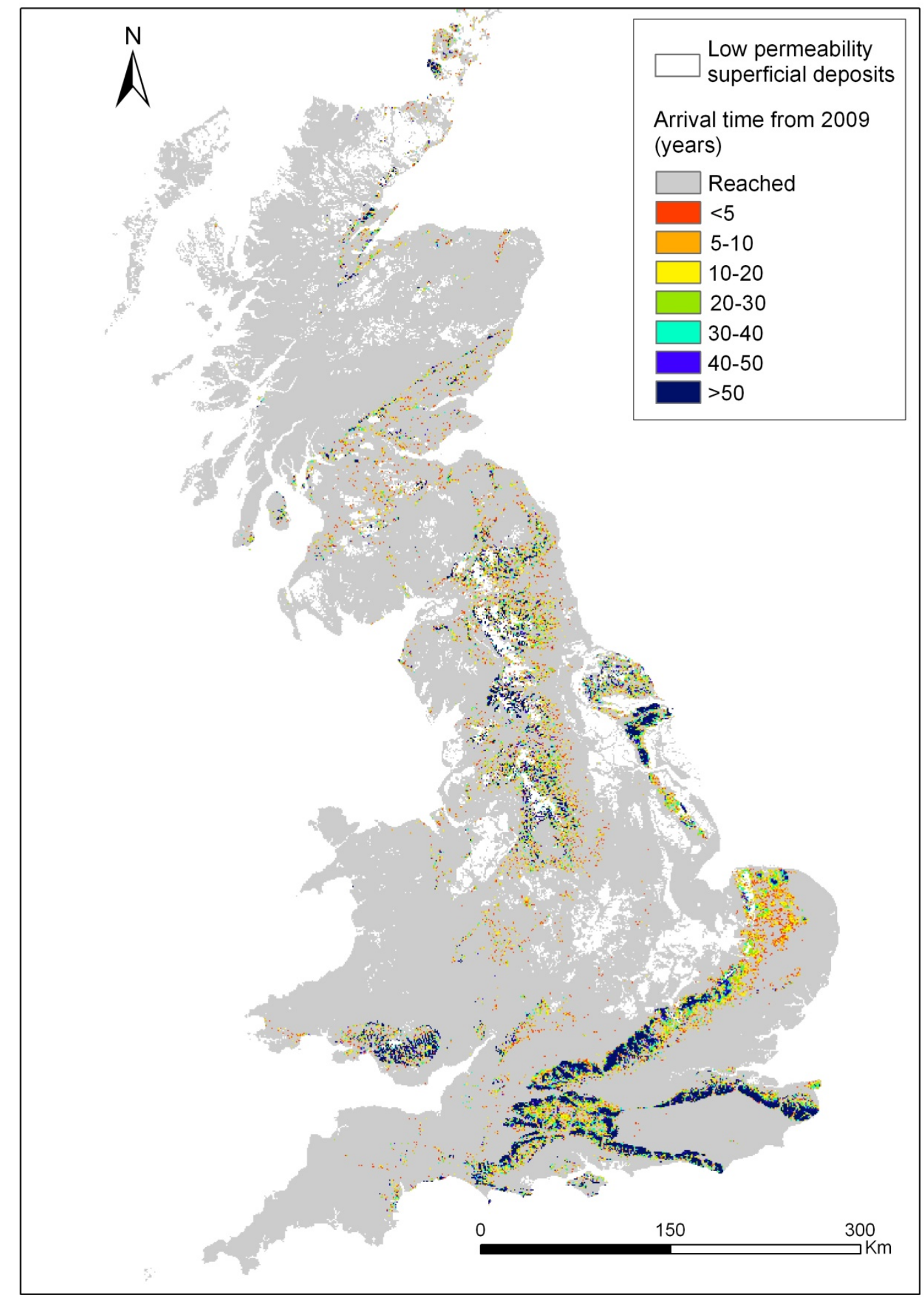

Figure 7. Model estimate of how long after 2009 the peak nitrate input will arrive at the water table. Low permeability superficial deposits not coloured. 


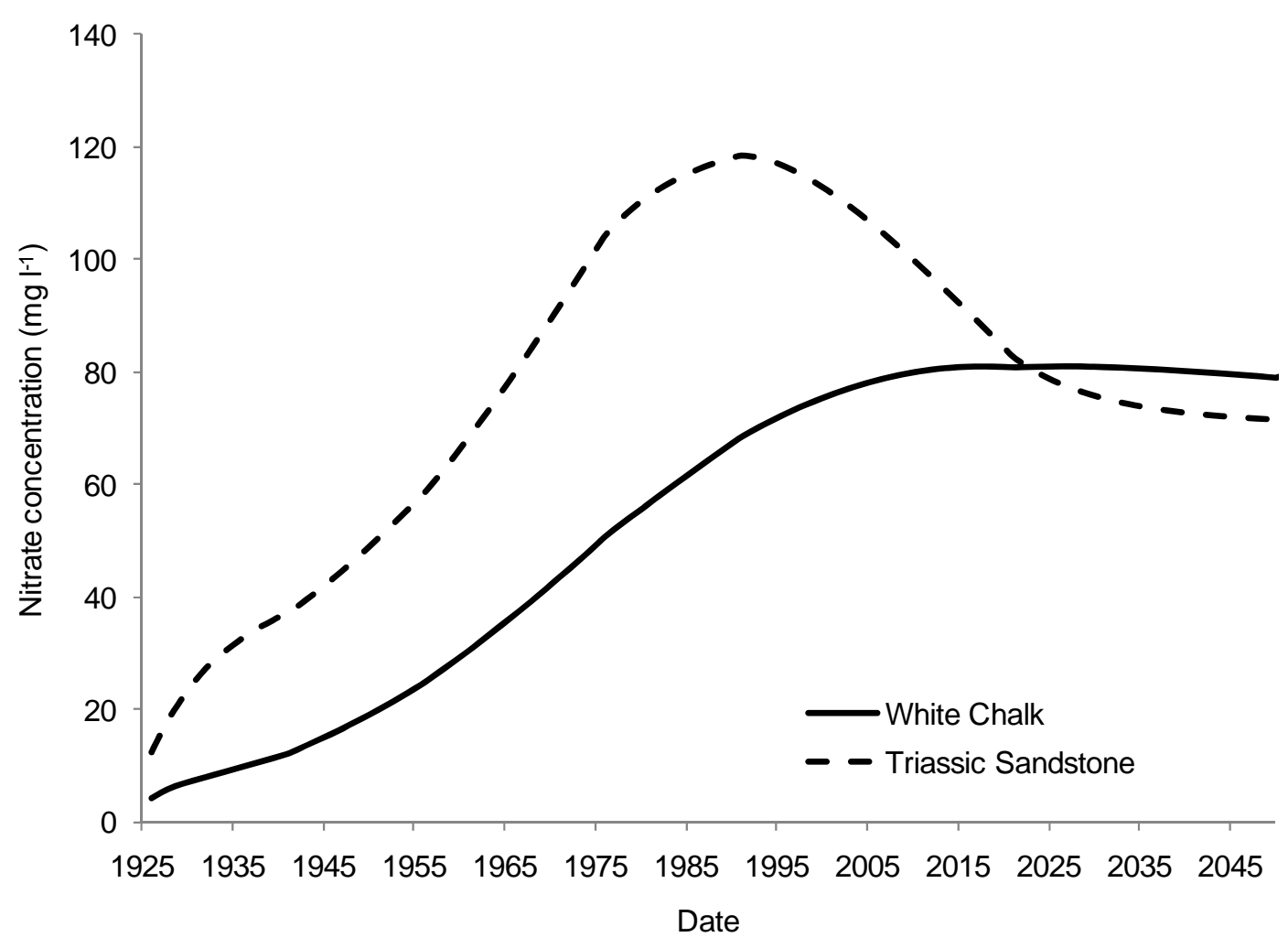

Figure 8. Predicted time series of nitrate concentration arriving at the water table of the two major aquifers of Great Britain 